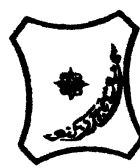

Bayero Journal of Pure and Applied Sciences, 8(2): 233 - 238

Received: December, 2015

Accepted: December, 2015

ISSN $2006-6996$

\title{
EFFECTS OF DIFFERENT HEAT PROCESSING METHODS ON THE ANTINUTRITIONAL FACTORS (ANFS) LEVEL OF $P$, reticulatum SEED MEAL
}

\author{
${ }^{1}$ Haruna, M., ${ }^{2}$ Bichi, A. H., ${ }^{3}$ Ibrahim, S. and ${ }^{4}$ Sambo, F. \\ ${ }^{1}$ Department of Biology Kano University of Science and Technology, Wudil, Kano. \\ ${ }^{2}$ Department of Fisheries and Aquacultural Technology, Federal University Dutsin -Ma, Katsina. \\ ${ }^{3}$ Department of Biological Sciences, Bayero University, Kano. \\ ${ }^{4}$ Department of Animal Health and Production. College of Agriculture Hadejia, Jigawa State
}

\section{ABSTRACTS}

The antinutritional factors (ANFs) in raw and differently heat processed $P$. reticulatum seed meal were evaluated. The seed was processed as raw seed (T1), 30 minutes boiled (T2), 60 minutes boiled (T3), traditionally boiled (T4), 40 minutes toasted (T5), 80 minutes toasted (T6), 120 minutes toasted (T7) and traditionally roasted seed (T8). The seed meal was evaluated for saponin, tannin, cyanide, oxalate, phytate and phenols. The result showed that heat processing significantly $(P<0.05)$ affected the ANFs in the seed meal. Highest value of saponin $(0.07 \mathrm{mg} / 100 \mathrm{~g})$ was recorded in $T 1$, while zero level of saponin was recorded in $T 4$. The highest value $(0.26 \mathrm{mg} / 100 \mathrm{~g})$ of tannin was recorded in $T 1$, while 74 recorded the least value $(0.05 \mathrm{mg} / 100 \mathrm{~g})$. Cyanide highest value of $(0.17 \mathrm{mg} / 100 \mathrm{~g})$ was observed in T1, while T4 recorded the least value $(0.02 \mathrm{mg} / 100 \mathrm{~g})$. The highest oxalate level was observed in T1 $(0.04 \mathrm{mg} / 100 \mathrm{~g})$ and zero level was recorded in T3, T4 and T8. Phytate highest level $(0.14 \mathrm{mg} / 100 \mathrm{~g})$ was recorded in $\mathrm{T} 1$, and zero level of phytate was recorded in T4. The highest phenol level was observed in $T 1(0.06 \mathrm{mg} / 100 \mathrm{~g})$ while zero level of phenol was recorded in T4. T4 is the most effective processing method that reduced all the ANFs with $100 \%$ reduction in saponin, oxalate, phytate and phenols. The processing methods used reduced the seed ANFs and therefore, indicated the possible utilization of the seed in animal feed formulation (fish inclusive).

Keywords: Antinutritional factors, heat, $P$. reticulatum, processing, seed.

\section{INTRODUCTION}

$P$. reticulatum is a shrub or small tree $5-10 \mathrm{~m}$ high having a bushy spherical canopy, with a trunk that is often twisted, and possessing a dark brown, fibrous and deeply longitudinally fissured outer bark and pink to red inner side of the bark. The leaves are bilobed (split in half in cattle hoof shape) and covered below by a reddish pubescence and are $7.5-16 \mathrm{~cm}$ long and $10-18 \mathrm{~cm}$ broad. The flowers are usually white and fragrant. The flowers are clustered in short hairy, axillary racemes $4-5 \mathrm{~cm}$. The petals of the flower are white with pink stripes, while the pods are woody, flat, straight, undiluted or twisted, hard, glabrous or sparsely pubescent, indehiscent and persisting, many seeded, up to $25 \mathrm{~cm}$ long $\times 5 \mathrm{~cm}$ wide and dark brown when ripe (Adjanohoun et al., 1991; Assi and Guinko, 1991 ; Vodouhe et al., 2010). The pod contains the seed. The plant fibre is strong; the wood is heavy and hard. The wood is liable to attacks by termites and borers. The wood is good source of fire wood, because it does not burn fast. Synonyms to $P$. reticulatum in the past includes Bauhinia thonningii (Schumach.), Bauhinia reticulate (DC), Bauhinia abyssinica (A. Rich.), Bauhinia pyrrhocarpa (Hochst) and Piliostigma pyrrhocarpum (Hochst) (Watt and Breyer - Brandwijk, 1962).
The local Nigerian names of $P$. reticulatum are Kargo (Or Kalgo) in Hausa (Northern Nigeria), Abafe in Yoruba language (Western Nigeria) and Okpo-atu in Igbo (Eastern Nigeria) (Dalziel, 1937; Burkill, 1995). Other common names include camel food (English); pied de chameau, semallier (France), Musacanca (Portugal) (Vodouhe et al., 2010). The plant is also known as Barkee - hi in fulfulde by Fulani in Nigeria (Roger and Mallam, 2006).

The members of the genus Piliostigma occur in tropical Africa and Indo-Malaya. The two African species $P$. reticulatum (DC.) Hochst and $P$. thonningii (Schum.) milne - Redhead, inhibit dry and moist savannahs, respectively (Allen and Allen, 1981).

Although there is limited information on the use of $P$. reticulatum seed as ingredients in livestock feed formulation. Akin-Osanaiye (2009) conducted a research on the nutritional potentials of $P$. reticulatum with a view of exploitation of plant seeds as an alternative plant protein source for human and livestock feed formulation.

Processing feedstuff make it safe for consumption. The factors that affect nutrients content resulting from feedstuff processing are; sensitivity of the nutrients to light, heat, oxygen (Morris et al., 2004). 
The different ways of feed stuff processing may affect significantly the concentration and availability of minerals, vitamins and other essential compounds in the feedstuff. To improve the nutritional quality and to provide effective utilization of legumes for animal feed, it is important to establish a processing method (s) that will remove or reduce the anti-nutritional factors. Various processing methods have been used in legume seeds (Farran et al, 2001; Barbour et al., 2001). The aim of the study was to determine the processing method that will reduce the antinutritional factors in the seed for animal (fish inclusive) feed formulation.

\section{MATERIAL AND METHODS}

\section{Seed Samples Collection and Identification}

Dry pods of Piliostigma reticulatum were obtained from Damfamin -Tofa, Ganduje Village, of Dawakin- Tofa local government area and new campus Bayero University Kano, all in Kano state. Kano is in the Sudan Savannah of Nigeria. It lies within latitude $11^{\circ} 30^{\prime \prime} \mathrm{N}$ and longitude $8^{\circ} 30^{\prime} \mathrm{E}$ and at an altitude of about 400 $\mathrm{m}$ above sea level (Olofin, 2008). The pods were treated using motor and pestle and winnowed on a tray by blowing air through to remove the chaff in order to have a clear seeds for the research.

The plant and the Pods Samples were identified in the department of biological scienses, Ahmadu Bello University, (ABU) Zaria.

\section{Seed Processing}

The collected seed samples were divided into eight (8) portions and processed differently, a modification of Anwa et al. (2007) Method as follows-

Treatment one $(\mathrm{T} 1)=$ raw $P$. reticulatum seed (RPRS), Treatment two $(\mathrm{T} 2)=30$ minutes boiled $P$. reticulatum seed $\left(\mathrm{BPRS}_{30}\right)$ Treatment three $(\mathrm{T} 3)=60$ minute boiled $P$. reticulatum seed $\left(\mathrm{BPRS}_{60}\right)$, Treatment four $(\mathrm{T} 4)=$ traditionally boiled $P$. reticulatum Seed $\left(\mathrm{BPRS}_{\mathrm{T}}\right)$, Treatment five $(\mathrm{T} 5)=40$ minutes toasted $P$. reticulatum seed $\left(\mathrm{TPRS}_{40}\right)$, Treatment six $(\mathrm{T} 6)=80$ minutes toasted. $P$. reticulatum Seed $\left(\right.$ TPRS $\left._{80}\right)$, Treatment seven $(T 7)=120$ minutes toasted $P$. reticulatum Seed $\left(\right.$ TPRS $\left._{120}\right)$ and Treatment eight $($ T8 $)=$ Traditionally roasted $P$. reticulatum Seed $\left(\mathrm{RPRS}_{\mathrm{T}}\right)$.

The raw $P$. reticulatum seed samples were boiled with clean bore hole water using one part of the raw seeds to ten (10) parts of the bore hole water 1:10 (W/V) at the ratio of 5kg: 10litres (Vadivel and Pugalanthi, 2007) in an aluminum pot of 15litres capacity on a stable flame gas cooker for the respective treatment periods that has to do with boiling. The water boiled at temperature of $100^{\circ} \mathrm{C}$ before the seeds were poured into the pot. Time of the boiling was monitored using stop watch. Traditional boiling was carried out using bigger aluminum pot on fire wood as source of heat with excess water to seed ratio. The boiling was continued until the seeds were very soft to allow for hand de-hulling. Dense ox- brown exudates were observed during boiling and it became more pronounced as the duration of boiling increased. Toasting was done using an electric oven (DHG - 9101 model) set at $75^{\circ} \mathrm{C}$ for each processing that had to do with toasting. Traditional roasting was done by constantly stirring the raw seed to prevent charring in a dry 5 minutes pre-heated open metal pan (traditionally made) using fire wood heat until browned The boiled seed samples were spread and allowed to cool on clean trays, while the roasted and toasted seeds were exposed to air on trays in the laboratory to hasten cooling. The processed seed samples were milled separately into a fine powdered form and were then stored in air tight containers separately in a cool place for chemical analysis.

The experimental design used was complete randomize design (CRD) and the treatments were in triplicates.

\section{Determination of the Seed Anti-Nutritional Factors}

Antinutritional factors of the seed were determined using diverse standard methods viz: saponin was estimated using Hudson and El-Difrawi (1979) method, tannin (AOAC, 1980), cyanide (AOAC, 1984), oxalate (Abeza et al., 1968), phytate (Reddy et al., 1982) and phenols by Obadoni and Ochuko (2001).

\section{Statistical Analysis}

The data generated during the seed antinutritional factors analysis was analysed using One-way Analysis of Variance (ANOVA) and the differences among the means were tested for significance using Duncan Multiple Range Test (Duncan, 1955) at 95\% level of probability. The statistical packages used were SAS package version 9 (SAS, 2002) of SAS Institute Inc. Cary. NC. USA

\section{RESULTS}

The antinutritional factors levels in raw and differently heat processed $P$, reticulatum seed meal (DHPPRSM) $(\mathrm{mg} / 100 \mathrm{~g})$ are presented in Table 1.

There was significant difference in levels of antinutional factors between the raw and the differently heat processed $P$. reticulatum seed meal (DHPPRSM) except saponin and oxalate in T5 (40 minutes toasted seed) $(P<0.05)$ (Table 1$)$.

The level of saponin showed no significant difference ( $\mathrm{P}>0.05$ ) between T2, T5, T6 and T7 and also between $\mathrm{T} 3$ and $\mathrm{T} 8$. Treatment 1 had the highest saponin level and treatment 4 recorded zero level of saponin (Table 1). Among the treated seed, treatment 5 and 6,2 and 7 and treatment 3 and 8 showed no significant difference in tannin level $(P>0.05)$. Treatment 3 had the least mean tannin values after T4. There was no significant difference between treatment 3, 4, 7 and 8 in cyanide level at $(P>0.05)$ (Table 1). Oxalate showed no significant difference between treatments 3,4 and 8 all with zero level $(P>0.05)$. Treatment 1 had the highest oxalate level (Table 1).Phytate levels showed no significant difference between treatments 2,5 and 6 and also between treatments $3,4,7$ and 8 ( $P>0.05)$, however, treatment 4 recorded zero levels while treatment 1 has the highest values of phytate (Table 1$)$. The level of phenols showed no significant difference $(P>0.05)$ between treatments 3,7 and 8 and also so did for treatment 2, 5 and 6 (Table 1).The percentage reduction of the anti-nutritional factors in raw and differently heat processed $P$. reticulatum seed meal are presented in Table 2. 
The best processing method in terms of anti nutritional factors percent reduction among the processing methods used was T4 then followed by T3 and T8. T5 was the least in the percentage reduction for all the anti-nutritional factors analyzed with exception of phytate (Table 2). Total elimination of the anti-nutritional factors analyzed was observed in T4 with exception of tannin and cyanide (Table 2).

Table 1: Antinutritional Factors Levels in Raw and Differently Heat Processed Piliostigma reticulatum Seed Meal (DHPPRSM) (mg/100g)

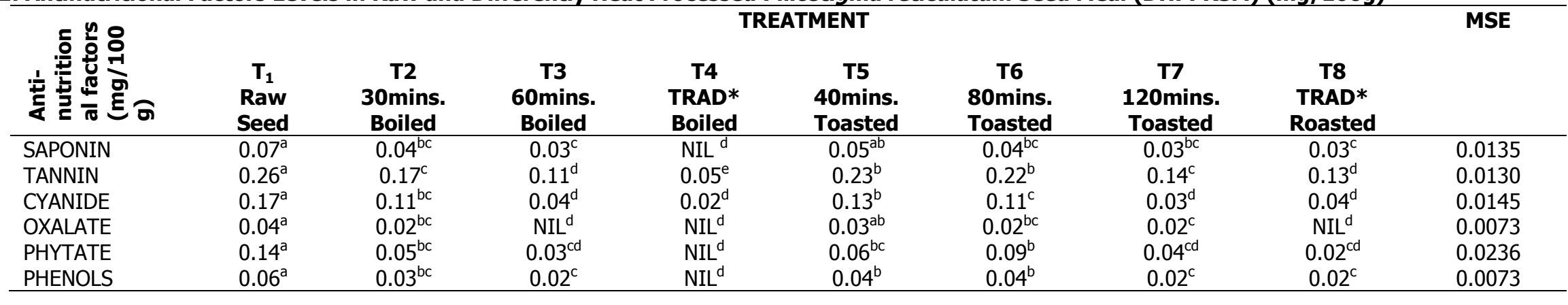

Means with the same letter within a raw are not significantly different $(P>0.05)$ with DMRT at $5 \%$ level of probability.

*TRAD = Traditionally

Table 2: Percentage of Anti-nutritional Factors Reduction in Raw and Differently Heat Processed P, retuculatum Seed Meal

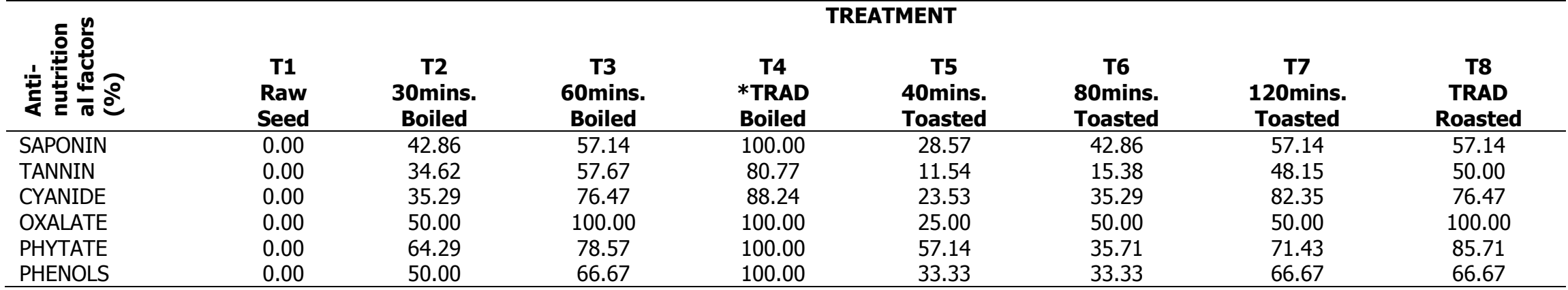

Means with the same letter within a raw are not significantly different $(P>0.05)$ with DMRT at $5 \%$ level of probability.

*TRAD = Traditionally 


\section{DISCUSSION}

The antinutritional factors (ANFs) analysis indicated the presence of saponins, tannins, cyanides, oxalates, phytates and phenols. Saponins, phenolics, cyanides were reported earlier by Jimoh and Oladiji (2005) in a related plant species (Piliostigma thonningii seed). Awe and Omojasola (2009) reported the presence of tannins, alkaloids, phenolics, triterpenses, phiobatinins in the barck extract of $P$. reticulatum Plant.

The antinutritional factors results showed that the seed meal have more tannins followed by cyanides, phytates, with moderate level of saponins. Oxalates recorded the least followed by phenols. There was significant difference $(P<0.05)$ in the level of antinutritional factors (ANFs) between the raw and the differently heat processed $P$. reticulatum seed meal (DHPPRSM) except saponins and oxalates in 40 minutes toasted (T5). Balogun (2011) reported similar trend on Bauhinia seeds.

Generally the ANFs levels reduce with increase in heat treatment period in this work, more especially in wet/moist heat treatments. The same findings were reported by Nwonsu (2011) on Oze seeds. T4 the recorded the best in term of percentage ANFs reduction in this study. This is in accordance with Khattab and Arntfield (2009) reports.

The level of saponin $(0.07 \mathrm{mg} / 100 \mathrm{~g})$ of raw $P$. reticulatum seed meal was found to be lower when compared to earlier reports on $A$. Lebbeck seed meal $(18 \%$ ) (8000mg/100g) (Auta and Anwa, 2007); Mango seed meal (14.21mg/g) (1421mg/100g) (Alatise, 2011) and B. monandra seed meal (2.74mg/100g) (Balogun, 2011). The differences observed might be due to differences in species and processing techniques.

The percentage reduction range of $28.57-100 \%$ of saponin recorded in this study was found higher when compared to $11.11 \%$ - $77.78 \%$ recorded by Auta and Anwa (2007) using different types of processing methods (boiling, toasting and roasting) on $A$. labbeck seed meal.

The level of tannins recorded in this study $(0.26 \mathrm{mg} / 100 \mathrm{~g})$ in the raw seed was higher than the level of $(0.002 \mathrm{mg} / \mathrm{g})(0.20 \mathrm{mg} / 100 \mathrm{~g})$ recorded by Auta and Anwa (2007) in the raw seed meal of Albizzia labbeck.

The percentage reduction range of $21.33-34.43 \%$ reported by Effiong and Umoren (2011) using multiprocessing methods on Mucuna urens was low compared to this study with of about (11.54-80.77\%). The least value of percentage reduction $(11.54 \%)$ in tannins was recorded in the toasted seed in this study (Table 2). Similar result was reported by Auta and Anwa (2007) on the toasted seed of Albezzia lebbeck. The value of hydrogen cyanide recorded in this study for the raw seed of $(0.17 \mathrm{mg} / 100 \mathrm{~g})$ was found to be lower when compared to the hydrogen cyanide content of certain common legume raw seeds such as vegetable cow pea (Sesquipedalis) (3.20mg/kg) $(0.32 \mathrm{mg} / 100 \mathrm{~g})$ (Udensi et al., 2007); Cajanus cajan $(396.60 \mathrm{mg} / \mathrm{kg})(39.66 \mathrm{~g} / 100 \mathrm{~g})$ (Iorgyer et al., 2009) and Mucuna urens $(56.30 \mathrm{mg} / 100 \mathrm{~g}$ ) ( Effiong and Umoren, 2011).

The hydrogen cyanide peorcentage reduction range of 23.53-88.24 in this study was found to be higher when compared to the percentage reduction of some common legume seeds using different heat processing methods such legume seeds include vegetable cowpea (12.50\% - 87.58\%) (Udensi et al., 2007) Cajanus cajan (53.43\% - 70.05\%) (Iorgyer et al., 2009) and Mucuna urens $(12.54 \%$ - $73.00 \%)$ (Effiong and Umoren, 2011).

The highest and lowest percentage reduction recorded at T4 (Traditionally boiled seed) and T5 (40 minutes toasted seed) respectively in this work is on accordance with Balogun (2011) reports that the levels of antinutrients in the boiled samples were more reduced to a considerable level than in the toasted samples.

More higher values of oxalate of raw legume seed antinutritional factors (oxalate) were reported compared to the value $(0.04 \mathrm{mg} / 100 \mathrm{~g})$ recorded in this study by many other workers $280 \mathrm{mg} / 100 \mathrm{~g}$ (Auta and Anwa 2007) on Albizzian lebbeck seed meal; $0.83 \%$ (830mg/100g) (Iorgyer et al., 2009) on Pigean pea seed meals; $12.08 \mathrm{mg} / 100 \mathrm{~g}$ (Balogun, 2011) on $B$. monandra seed meal and $33.00 \mathrm{mg} / 100 \mathrm{~g}$ (Effiong and Umorens, 2011) on Mucuna urens seed meal. These differences might be due to species variation, seed condition (wet or dry), geographical location, climate, processing methods among others.

The values of percentage reduction of oxalate $(25.00 \%$ $-100 \%$ ) recorded in this study were higher when compared to those of other various researchers who reported reduction range of oxalate with similar processing method on legume seeds (Auta and Anwa, 2007; Iorgyer et al., 2009 and Balogun, 2011).

The value of phytate $(0.14 \mathrm{mg} / 100 \mathrm{~g})$ of the raw seed recorded in this study was low compared to the findings of various researchers who reported on the phytate contents of some legume raw seeds. $A$. lebbeck seed meal $(0.26 \mathrm{mg} / \mathrm{g})(26 \mathrm{mg} / 100 \mathrm{~g})$ (Auta and Anwa 2007), Lathyrus sativus L. (352.04mg/100g) (Gashaw, 2010) and soybean $(345.00 \mathrm{mg} / 100 \mathrm{~g}$ ) (Ari et al., 2012).

The percentage reduction range values of (35.71$100 \%$ ) obtained in this study for phytate were higher than the values obtained by Auta and Anwa (2007) for A. Lebbeck seed (25.00-62.50\%); Udensi et al. (2007) for vegetable cow pea (7.06-68.34\%); Gashaw (2010) for Lathyrus sativus L. (29.76-74.32\%) and Ari et al. (2012) for soybean (48.12-71.71\%).

The highest reduction of phytic acid (phytate) in the boiled seed T4 (Traditionally boiled seed) is in accordance of Udensi et al. (2007) reports on vegetable cow pea (Sesquipedalis) seed, using thermal processing methods (boiling, roasting and autoclaving). The lowest percentage reduction recorded at T5 (40 minutes toasted seed) agreed with Ari et al. (2012) findings on soybean seed who reported that toasted soybean gave the least reduction in phytic acid $(48.12 \%)$. The values of phenols $(0.06 \mathrm{mg} / 100 \mathrm{~g})$ recorded in the raw seed of this study was more closer 
to the values of $0.41 \mathrm{mg} / 100 \mathrm{~g}$ reported by Fila et al. (2012) for dry rambutan seed.The percentage reduction of $33.33-100.00 \%$ of phenol observed in this study was higher than $53.00-78.00 \%$ recorded by Doss et al. (2011) using soaking, cooking and autoclaving on Jack bean seed. In the present study, T4 (Traditionally boiled seed) recorded zero phenol level, therefore chosen as the best method for the phenols reduction in this study.

\section{REFERENCES}

Abeza, R.H.; Blake, J.T and Fisher, E.J. (1968). Oxalate Determination: Analytical problems Encountered with certain plant species .Journal of the Association of Official Agricultural Chemists, 51:963-965.

Adjanohun, E., Ahiyi, M.R.A., Assi, L.A., Dramane, K., Elewude, J.A., Fadoju, S.O., Gbile, Z.O., Goudote, E., Johnson, C.L.A., Keita, A., Morakinyo, O., Ojewole, J.A. and Sofowora, E.A. (1991). Traditional medicine and pharmacopoeia: contribution to ethnobotanical and floristic studies in Western Nigeria. Organization of African Unity/Scientific Technical and Research Commission 93 337, 343 and 354.

Akin-Osanaiye, B.C., Agbaji, A.S. and Abdulkadir, O.M. (2009). Proximate composition and the functional properties of defatted seed and protein Isolates of Kargo ( $P$. reticulatum) seed. AJFAND Online Vol. 9 No. 6 Pp $1365-$ 1377.

Alatise, S.P. (2011). Utilization of Fermented Mango (Mangifera indica) seed meal in the practical diet of Nile Tilapia, (Oreochromis niloticus). Unpublished M. Sc.Thesis, University of Agriculture Abeokuta, Nigeria. $94 \mathrm{Pp}$.

Allen, O.N. and Allen, E.K. (1981). The leguminosae: A source Book of characteristics, uses and Nodulation. The University of Wisconsin Press, USA. Xii - xxiii: 52.

Anwa, E.P., Auta, J. Abdullahi, S.A. and Bolorunduro P.I. (2007). Effects of Processing on Seeds of Albizzia lebbeck. Proximate Analysis and Phytochemical Screening. Research Journal of Biological Sciences, 2 (1): 41-44

AOAC (1980), Official Method of Analysis $13^{\text {th }}$ edition, Association of Official Analytical Chemist Washington, D.C 423pp.

AOAC(1984): Official Methods of Analysis, Association of Official Analytical Chemist $14^{\text {th }}$ edition Washington D.C

Ari, M.M., Ayanwale, B.A., Adama, T.Z. and Olatunji, E.A. (2012). Evaluation of the chemical composition and Anti-Nutritional Factors (ANFs) levels of different thermally processed soybean. Asian Journal of Agricultural Research, 6: $91-98$.

Assi, L.A. and Guiniko, S. (1991). Plants used in traditional medicine in West Africa. Swiss

\section{CONCLUSION}

This study has showed the importance of head processing on the studied seed, since it reduced the ANFs level of the seed. Among the processing methods adopted in this study, traditionally boiling method appeared to be the best with zero level in some of the ANFs studied. Thus the study showed the need of processing feed ingredients in any animal feed formulation in order to reduce the effects of ANFs in the feed.

Centre for Scientific Research in Ivory cost. And Roche Africa Research Foundation. 17$18,56$.

Auta, J. and Anwa, E.P. (2007). Preliminary studies on Albizzia lebbeck seeds: Proximate Analysis and Phytochemical screening. Research Journal of Biological Sciences, 2 (1): 33 - 35.

Awe, S. and Omojasola, P.F. (2009). A Comparative Study of the Antibacterial Activity of Piliostigma reticulatum Bark Extract with some Antibiotics. Ethnobotanical Leaflets, 13: 1197 $-1204$.

Balogun B.I. (2011): Growth Performance and Feed Utilization of Clarias gariepinus (Teugels ) Fed Different Dietary Levels of Soaked Bauhinia monandra (Linn) Seed Meal and Sun-dried Locust Meal (Schistocerca gregaria ) Ph.D Thesis Postgraduate School Ahmadu Bello University, Zaria 184pp

Barbour, E.K., M. Kallas and M.T. Farran (2001). Immume response to Newcastle disease virus in broilers: A useful model for the assessment of detoxification of ervil seeds. Rev. Sci. Tech. Off..Int. EP. Z,20: $785-790$.

Burkill, H.M. (1995). The useful plants of West Tropical Africa. Edition 2, Volume 3, Families J-L. Royal Botanic Gardens, Kew. 144-150.

Dalziel, J.M. (1937). The useful plants of West Tropical Africa. Grown agents, London. 174-175.

Doss, A., Pugalenthi, M., Vadival, V.G., Subhashini, G. and Anitha, S.R. (2011). Effect of processing technique on the nutritional composition and antinutrients content of underutilized food legumes Canavalia ensiformis L.D.C International Food Research Journal, 18 (3): $965-970$.

Duncan, D.B. (1955). Multiple range and multiple Ftest. Biometrics. $11,1-42$.

Effiong, O.O. and Umoren U.E. (2011). Effect of Multiprocessing techniques on the chemical composition of Horse Eye bean (Mucuna urens) Asian Journal of Animal Scuences, 5: $340-348$.

Farran, M.T., P.3 Dakessian, A.H. darwish, M.G. uwayjan, H.G Dbouk, F.T, Seliman \& V.M Ashkarin. (2001). Performance of broilers production and egg quality parameters of laying hens fed $60 \%$ raw and treated common vetch (Vicia ervilia) seeds. Poult Sci., 80:203-208. 
Fila, W.O., Johnson, T.J., Edem, P.N., Odey, M.O., Ekam, V.S., Ujong, U.P. and Eteng, O.E. (2012). Comparative antinutrients assessment of pulp, seed and rind of rambutan (Nephelium lappaceum). Annals of Biology Research, 3 (11): 5151 - 5156.

Gashaw, G. (2010). Effects of Traditional Food Processing Methods on Nutrient Compositions and Anti-nutritional Factors of Grass Pea (Lathyrus sativus L) Foods consumed, in Ethiopia. Published M.Sc. Thesis Graduate Studies Program, Addis Ababa University, Ethiopia. 69Pp.

Hudson, B.J.F and El-Difrawi, E.A. (1979). The Sapogenins of the seeds of four lupin species Journal of plant food, 3:181-186.

Iorgyer, M.I., Adeka, I.A., Ikondo, N.D. and Okoh, J.J. (2009). The Impact of Boiling periods on the proximate composition and level of some antinutritional factors in pigeon pea. (Cajanus cajan) seeds. PAT 2009; 5 (1): $92-102$ ISSN; $0794-5213$

Jimoh, F.O. and Oladiji, A.T. (2005) Preliminary Studies on Piliostigma thonningii Seeds: Proximate analysis, mineral composition and pytochemical screening. African Journal of Biotechnology, 4: (12) PP 1439- 1442.

Khattab, R.Y. and Arntfield S.D.(2009). Nutritional quality of legume seeds as affected by some physical treatments 2 . Antinutritional factors. LWT - Food Science and Technology, 42: $1113-1118$.

Morris, A., Barmelt, A and Burrows, O.J (2004). Effect of mocersing on nutrient content of foods. Cajarticles, 37 (3): 160-164.
Nwosu, J.N. (2011). The Effects of processing on the antinutritional properties of Oze (Bosqueia angolensis) seed. Journal of American Science, 7 (1) : 1-6.

Obadoni B.O. and Ochuiko, P.O. (2001). Phytochemical Studies and Comparative Efficacy of Crude Extracts of Some Homeostatic Plants in Edo and Delta States of Nigeria. Globa J. Pure and Appl. Sci., 8. 203208.

Olofin, E.A.(2008).General introduction In: E.A, Olofin, A.B. Nabegu and A.M.Dambazau (eds). Wudil within Kano region, $A$ geographical synthesis. Adamu Joji publishers Kano city, Kano. Pp 1-4

Reddy, M.R; Sathe, S.K; Salunkle, D.K. (1982), Phytate in Legumes and Cereal. Advances in Food Research, 28:1-92.

Roger, B. and Mallam, D. (2006). Fulfulde names for plants and trees in Nigeria, Cameroun, Chad and Niger. Cambridge CBI 2AC U.K

Udensi, E.A., Ekwu, F.C. and Isinguzo J.N. (2007). Antinutritional factors of vegetable cowpea (Sesquipedalis) seeds during thermal processing Pakistan Journal of Nutrition, 6 (2): $194-197$.

Vadivel, V. and Pugalenthi, M. (2007). Biological value and protein quality of raw and processed seeds of Mucuna pruriens var. utilis. Livestock Research for Rural Development, 19 (7) 11pp.

Vodouhe, F.G., Ndanikou, S. and Achigan-Dako, E.G. (2010). Piliostigma reticulatum (DC.) Hoechst. In: Brink, M. and Achigan-Dako, E.G. (Editors). Prota 16: Fibres/plantes a fibres. (CD-Rom). PROTA, Wageningen, Netherlands. 